University of Nebraska - Lincoln

DigitalCommons@University of Nebraska - Lincoln

Agronomy \& Horticulture - Faculty Publications

Agronomy and Horticulture Department

May 2005

\title{
Backcross breeding for improved resistance to common bacterial blight in pinto bean (Phaseolus vulgaris L. )
}

\author{
Nedim Mutlu \\ University of Nebraska-Lincoln, nmutlu2@unl.edu \\ P. Miklas \\ USDA-ARS, Vegetable and Forage Crop Research Unit \\ J. Reiser \\ University of Nebraska-Lincoln \\ D. Coyne \\ University of Nebraska-Lincoln
}

Follow this and additional works at: https://digitalcommons.unl.edu/agronomyfacpub

Part of the Plant Sciences Commons

Mutlu, Nedim; Miklas, P.; Reiser, J.; and Coyne, D., "Backcross breeding for improved resistance to common bacterial blight in pinto bean (Phaseolus vulgaris L. )" (2005). Agronomy \& Horticulture -- Faculty Publications. 13.

https://digitalcommons.unl.edu/agronomyfacpub/13

This Article is brought to you for free and open access by the Agronomy and Horticulture Department at DigitalCommons@University of Nebraska - Lincoln. It has been accepted for inclusion in Agronomy \& Horticulture -Faculty Publications by an authorized administrator of DigitalCommons@University of Nebraska - Lincoln. 


\title{
Backcross breeding for improved resistance to common bacterial blight in pinto bean (Phaseolus vulgaris L.)
}

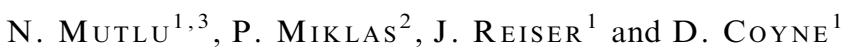 \\ ${ }^{1}$ Department of Agronomy and Horticulture, University of Nebraska, Lincoln, NE 68683, USA; E-mail: nmutlu2@unl.edu or \\ severmutlu@hotmail.com; ${ }^{2}$ USDA-ARS, Vegetable and Forage Crop Research Unit, 24106 North Bunn Road, Prosser, WA \\ 99350, USA; ${ }^{3}$ Present address: Bati Akdeniz Tarimsal Arastirma Enstitusu Mudurlugu P.K. 35-130 07100 Antalya, Turkey \\ With 1 figure and 3 tables
}

Received October 1, 2004/Accepted October 30, 2004

Communicated by G. Röbbelen

\begin{abstract}
Common bacterial blight (CBB) caused by Xanthomonas campestris pv. phaseoli reduces common bean (Phaseolus vulgaris L.) yield and quality worldwide. Genetic resistance provides effective disease control; however, a high level of resistance is difficult to attain and does not exist in pinto bean, the most important dry bean market class in North America. Our objective was to determine if a backcross breeding approach with the aid of molecular markers linked to quantitative trait loci (QTL) for resistance to $\mathrm{CBB}$ in a donor parent could be used to attain higher levels of resistance to $\mathrm{CBB}$ in pinto bean. QTL conditioning $\mathrm{CBB}$ resistance from the donor parent XAN 159 were introgressed into the recurrent parent 'Chase' using classical backcross breeding and intermittent marker-assisted selection. 'Chase' pinto bean is moderately resistant and the breeding line XAN 159 is highly resistant to Xanthomonas campestris. Marker assays confirmed the presence of independent QTL from GN no. 1 Sel 27 and XAN 159 in advanced backcross-derived pinto bean lines with improved $\mathrm{CBB}$ resistance. Agronomic characteristics of 'Chase' were fully recovered in the backcross-derived lines. An important QTL for CBB resistance from XAN 159 on linkage group B6 was not introgressed because tight linkage between this QTL and the dominant $V$ allele that causes an unacceptable black-mottled seed coat colour pattern in pinto bean could not be broken.
\end{abstract}

Key words: Phaseolus vulgaris - Xanthomonas campestris pv. phaseoli, syn. Xanthomonas axonopodis pv. phaseoli - markerassisted selection — quantitative trait locus-resistance

Common bean (Phaseolus vulgaris L.) is a legume of worldwide significance and a staple food of the rural poor in developing countries. The common bacterial blight (CBB) disease caused by Xanthomonas campestris pv. phaseoli (Smith) Dye $(X c p)$ reduces bean yield and seed quality. The CBB pathogen attacks all aerial plant parts, including leaves, pods and seeds. Infected seeds have atypical colour, thus reducing commercial value. Although, primarily a seed-borne disease, planting infected seeds does not always result in systemic transmission of the pathogen from the vascular tissues of mature plants to the next seed generation (Aggour et al. 1989).

Common bacterial blight is difficult to control with chemicals. If available, resistant cultivars provide the most effective method of control, especially when incorporated within an integrated disease management system that promotes the planting of certified seeds. The complex nature of resistance and the large environmental effect on symptom development, as supported by low to moderate heritability $\left(h^{2}\right)$ estimates (reviewed by Singh and Munoz 1999), makes screening for
CBB resistance difficult. For instance, a line may have resistant leaves but susceptible pods, or vice versa (Coyne and Schuster 1974, Schuster et al. 1983).

Genetic studies based on quantitative trait locus (QTL) analyses support the existence of at least four major QTL responsible for $\mathrm{CBB}$ resistance in common bean (reviewed by Kelly et al. 2003). XAN 159 has been shown to possess two major QTL for resistance to CBB (Jung et al. 1997). The QTL on linkage groups B6 and B8 are tightly linked with sequencecharacterized amplified region (SCAR) markers BC420 (Yu et al. 2000) and SU91 (Pedraza et al. 1997), respectively. Miklas et al. (2000) showed that the BC420 and SU91 SCAR markers are derived from tepary bean (Phaseolus acutifolius A. Gray) and thus reside on the same genomic fragment as the introgressed genes (QTL) for CBB resistance. 'Chase' has the major-effect resistance QTL linked with the SAP6 SCAR marker located on linkage group B10. SCAR markers tightly linked with three of the QTL on linkage groups B6, B8 and B10 (Miklas et al. 2003) improve selection efficiency over the random amplified polymorphic DNA (RAPD) markers, because of multiplex polymerase chain reaction (PCR) and relative ease of scoring for complex inherited $\mathrm{CBB}$ resistance. The CBB-resistant dry bean germplasm XAN 159 acquired the B6 and B8 QTL from tepary bean (McElroy 1985, Jung et al. 1997, Miklas et al. 2003). The B10 QTL was derived from GN no. 1 Sel 27 (syn. Nebraska Great Northern No. 1 Selection 27) via the Great Northern Landrace Montana no. 5 (Miklas et al. 2003).

Successful applications of marker-assisted selection (MAS) in breeding for quantitatively inherited disease resistance in various crop plants have been reported. In a similar study, two molecular markers that explained $22 \%$ of the total variation for $\mathrm{CBB}$ resistance were effective $(70 \%)$ in selecting resistant individuals in common bean (Tar'an et al. 1998). MAS for a major QTL for scab (Fusarium graminearum) resistance with simple sequence repeat (SSR) markers combined with phenotypic selection was more effective than selection based solely on phenotypic evaluations in early generations in wheat (Zhou et al. 2003). The QTL for stripe rust (Puccinia striiformis Westend. f.sp. hordei Eriksson) resistance were introgressed into a genetic background unrelated to the mapping population with one cycle of marker-assisted backcrossing in barley (Toojinda et al. 1998). Five QTL for blackmold (Alternaria alternata) resistance in tomato were introgressed into cultivated tomato using MAS (Robert et al. 2001). Similarly, three QTL 
(accounting for $28 \%$ of the total variance) for resistance to southwestern corn borer (Diatraea grandiosella) were selected through MAS, that resulted with equivalent improvement for resistance compared with conventional selection in the $\mathrm{BC}_{1} \mathrm{~F}_{1}$ and $\mathrm{BC}_{2} \mathrm{~F}_{1}$ generations (Willcox et al. 2002).

Recently, CBB resistances from XAN 159, GN no. 1 Sel 27 and PI 207262 were combined to produce XAN 263 and XAN 309 , and combined with other sources to produce the VAX dry bean lines with high levels of CBB resistance (Singh and Munoz 1999, Singh 2001, Singh et al. 2001). Similarly, by pyramiding $X c p$ resistance from the donor parent XAN 159 with the moderate resistance present in the recurrent pinto bean parent 'Chase', we sought to determine if a classical backcross breeding approach with the aid of molecular markers linked to QTL for resistance to CBB in donor parent could be used to attain higher levels of resistance to CBB in a commercially acceptable pinto bean.

\section{Materials and Methods}

Plant materials: The donor parent XAN 159 was developed for resistance to $\mathrm{CBB}$ at the Centro International Agricultura Tropical (CIAT) (McElroy 1985) from the interspecific cross UI 114/PI 319441//PI 319443/3/'Masterpiece' cultured by Thomas and Waines (1984). XAN 159 is a low-yielding and poorly adapted medium seedsized dry bean with a black-mottled seed coat colour pattern on a speckled purplish grey background. 'Chase' pinto (Coyne et al. 1994), the recurrent parent, is a high-yielding, rust-resistant cultivar with moderate resistance to $X c p$. Plant growth conditions in the greenhouse were as described elsewhere (Park et al. 1999). The exception was that $\mathrm{BC}_{3} \mathrm{~F}_{1}$ plants were grown in a growth chamber maintained at a $25 \pm 2{ }^{\circ} \mathrm{C}$ day and $21 \pm 2^{\circ} \mathrm{C}$ night temperature regime and $12 \mathrm{~h}$ photoperiod.

Bacterial isolates: The $X c p$ isolate, Dominican Republic (DR) DR-7 obtained from A. Vidaver (University of Nebraska), was used for inoculation in this study. This isolate is highly virulent and stable, and has been extensively used in genetic and breeding studies in Nebraska. The preparation of isolate and the inoculation of trifoliolate bean leaves was as described previously (Park et al. 1999). The percentage of inoculated leaf area with CBB symptoms consisting of necrosis, watersoaking and/or chlorosis was recorded 14 and 21 days after inoculation.

Backcrossing: The $F_{1}$ plants from the initial cross 'Chase'/XAN 159 were backcrossed on 23 September 1997 with the recurrent parent 'Chase' (female). The resulting $\mathrm{BC}_{1}$ and subsequent backcrosses were screened using the greenhouse leaf-inoculation test described above to identify $F_{1}$ plants with the highest level of resistance for use as the donor parent (male) in the next backcross cycle. The parents and PC50 as a susceptible check were included in each test. All crosses and $\mathrm{BC}_{n} \mathrm{~F}_{1}$ inoculation tests were performed in the greenhouse. The subsequent selfed $\mathrm{BC}_{n} \mathrm{~F}_{2}$ populations from resistant $\mathrm{BC}_{n} \mathrm{~F}_{1}$ plants were also tested for $\mathrm{CBB}$ reaction in the greenhouse.

A total of five crosses, the initial cross and four backcrosses, with the recurrent parent were conducted ('Chase' * 5/XAN 159). The $X c p$ inoculation dates were 18 January $1998\left(\mathrm{BC}_{2} \mathrm{~F}_{1}\right), 23$ April 1998 $\left(\mathrm{BC}_{3} \mathrm{~F}_{1}\right), 29$ September $1998\left(\mathrm{BC}_{4} \mathrm{~F}_{1}\right)$ and 3 February $1999\left(\mathrm{BC}_{5} \mathrm{~F}_{1}\right)$.

Markers: Marker-assisted selection was used to confirm the presence of the two major (B6 and B8) QTL from XAN 159 and one minor (B10) QTL from 'Chase' in early $\mathrm{BC}_{1} \mathrm{~F}_{1}$ and $\mathrm{BC}_{2} \mathrm{~F}_{1}$ generations. Single-factor analysis of variance (ANOVA) for each pair-wise combination of quantitative trait and marker locus was used to analyse the data for detection of QTL affecting leaf resistance to the $X c p$ strain in $\mathrm{BC}_{1} \mathrm{~F}_{1}$ and $\mathrm{BC}_{2} \mathrm{~F}_{1}$ generations. Significant differences in trait associ- ations were based on $F$-tests $(\mathrm{P}<0.05)$. Loci with the lowest $\mathrm{P}$-value per QTL were chosen and were then added in a stepwise regression to select the best set of markers $(\mathrm{P}<0.05)$ for prediction of the total trait phenotypic variation explained $\left(R^{2}\right)$ by the QTL in question (Paterson et al. 1991). All statistical analyses were conducted using the Statistical Analysis System (SAS, 1981).

Total genomic DNA was extracted from lyophilized leaf tissue of $\mathrm{BC}_{1} \mathrm{~F}_{1}$ and $\mathrm{BC}_{2} \mathrm{~F}_{1}$ plants using the protocol followed by Skroch and Nienhuis (1995) and assayed for the presence of CBB resistance-linked markers. The E4.1150 RAPD marker was used to detect the CBB resistance QTL on linkage group B8 (Jung et al. 1997) (Table 1). The SCAR marker SU91 is linked with the same QTL (G. Jung, pers. comm., 2000). The $V$ locus, BC420 SCAR and P8.1000 and Y7.1200 RAPDs were used as markers for the resistance QTL on B6 (Table 1). The AP7.1800 RAPD was used to detect a minor QTL from XAN 159 on linkage group B10 (Table 1). PCR reaction mixes and thermal cycling profiles followed previously published protocols (Jung et al. 1997, Yu et al. 2000).

Total genomic DNA was extracted from fresh tissue bulked across three plants from each $\mathrm{BC}_{4} \mathrm{~F}_{5}$ and $\mathrm{BC}_{5} \mathrm{~F}_{4}$ line using a mini-prep procedure (Miklas et al. 1996). The DNA was assayed for the presence of the BC420 and SU91 SCARs linked with the B6 and B8 QTL derived from XAN 159 and the SAP6 SCAR linked with the B10 QTL present in 'Chase' using a single multiplex PCR reaction described by Miklas et al. (2000).

Selection of advanced $\mathbf{B C}$ lines: The $\mathrm{BC}_{4} \mathrm{~F}_{1}$ and $\mathrm{BC}_{5} \mathrm{~F}_{1}$ plants with the highest level of resistance to $\mathrm{CBB}$ in a greenhouse leaf inoculation test were selfed to produce $\mathrm{BC}_{4} \mathrm{~F}_{1: 2}$ and $\mathrm{BC}_{5} \mathrm{~F}_{1: 2}$ populations. The $\mathrm{BC}_{4} \mathrm{~F}_{1: 2}$ population, parents and $\mathrm{PC} 50$ as a susceptible check were screened for reaction to $\mathrm{CBB}$ in the greenhouse in 1999 using a randomized complete block design (RCBD) with two replicates. Subsequently, single $\mathrm{BC}_{4} \mathrm{~F}_{2: 3}$ and $\mathrm{BC}_{5} \mathrm{~F}_{1: 2}$ plants with acceptable pinto seed characteristics and resistance to $\mathrm{CBB}$ in the greenhouse (fall 1999) were selected. Single plant selections were made from seven $\mathrm{BC}_{4} \mathrm{~F}_{3: 4}$ and seven $\mathrm{BC}_{5} \mathrm{~F}_{2: 3}$ progeny lines expressing the highest resistance under natural infection in the field at Mitchell, NE (summer 2000) where susceptible checks and the recurrent parent 'Chase' had moderate CBB infection. The selections were increased in a winter nursery in Puerto Rico to produce $\mathrm{BC}_{4} \mathrm{~F}_{4: 6}$ and $\mathrm{BC}_{5} \mathrm{~F}_{3: 5}$ lines for testing in replicated field trials. Residual $\mathrm{BC}_{4} \mathrm{~F}_{4: 5}$ and $\mathrm{BC}_{5} \mathrm{~F}_{3: 4}$ seeds were planted for DNA extraction and MAS for CBB resistance-linked SCAR markers (described above).

Field evaluation of advanced $\mathbf{B C}$ lines: Selected $\mathrm{BC}_{4} \mathrm{~F}_{4: 6}$ and $\mathrm{BC}_{5} \mathrm{~F}_{3: 5}$ lines from the winter nursery with acceptable pinto bean seed characteristics and having the SAP6 and SU91 SCAR markers were evaluated for agronomic performance and field reaction to CBB in a trial planted at Mitchell, NE, on 6 June 2001. The experiment was repeated with the same set of lines planted on 31 May 2002 at Othello, WA, and 12 June 2002 at Mitchell, NE, using the $\mathrm{BC}_{4} \mathrm{~F}_{4: 7}$ and $\mathrm{BC}_{5} \mathrm{~F}_{3: 6}$

Table 1: Single-factor ANOva for QTL-linked markers conditioning resistance and $\mathrm{CBB}$ reaction in the greenhouse, for early $\mathrm{BC}$ generations with 'Chase' and XAN 159 as donor and recurrent parents respectively

Probability value/variation explained $R^{2}$

\begin{tabular}{lccc}
\cline { 3 - 4 } Marker & Linkage group & $\mathrm{BC}_{1} \mathrm{~F}_{1}$ & $\mathrm{BC}_{2} \mathrm{~F}_{1}$ \\
\hline E4.1150 & $\mathrm{B} 8$ & $0.0007 / 23$ & $0.0000 / 17$ \\
$V$ & $\mathrm{~B} 6$ & $0.0006 / 24$ & $0.0000 / 38$ \\
BC420 & $\mathrm{B} 6$ & $0.0029 / 19$ & $0.0000 / 25$ \\
Y7 & $\mathrm{B} 6$ & $0.0318 / 10$ & $0.0004 / 13$ \\
P8 & $\mathrm{B} 6$ & $0.0235 / 11$ & $0.0032 / 9$ \\
AP7 & $\mathrm{B} 10$ & $0.0105 / 14$ & $0.0255 / 5$ \\
\hline
\end{tabular}


seed generation. The parents, and 'Othello' pinto as a susceptible check, were included. Single-row plots of each entry were arranged in a RCBD with three and four replications for the WA and NE trials, respectively. The row length per plot was $4.5 \mathrm{~m}$ long and spaced $0.75 \mathrm{~m}$ apart for NE and $3 \mathrm{~m}$ long and $0.56 \mathrm{~m}$ apart for WA. The seeding rate was approximately 220000 seeds/ha for NE in 2001 and $280000 \mathrm{seeds} / \mathrm{ha}$ for NE and WA in 2002. The plots were fertilized, irrigated and weeded to promote normal growth. Field plots were not inoculated with CBB.

Natural infections of $\mathrm{CBB}$ were recorded for the NE trials on 30 August 2001 as percentage leaf area with CBB symptoms, and 1 September 2002, as a disease severity score using a five-point scale (1, no symptoms; $2,<10 \% ; 3,10-25 \% ; 4,25-50 \%$; and $5,50-100 \%$ CBB infection). The plots were harvested on 28 September 2001 and 14 October 2002 in NE and on 14 September 2002 in WA to obtain the yield (kg/ha). Seed size was also measured (g/100 seed).

Seed colour: Seed colour readings for each entry in the 2001 trial were recorded on 11 November 2001, 43 days after harvest in order to provide time for seed browning and yellowing to occur. Three consecutive measurements were taken from the surface of Petri dishes completely filled with seeds of each line per replication. A Minolta Chroma Meter CR-300 (Minolta, Osaka, Japan) programmed for the Hunter Color Scale was used to record $L^{*}$ (brightness factor), and $b^{*}$ (yellowness) values. The $L^{*}$ - and $b^{*}$-values were obtained using a white colour standard.

Confirmation of field CBB resistance in greenhouse: Seven and two $\mathrm{BC}_{4} \mathrm{~F}_{4: 7}$ and $\mathrm{BC}_{5} \mathrm{~F}_{3: 6}$ lines, respectively, with the best field performance for $\mathrm{CBB}$ resistance, yield, and seed weight and colour were inoculated by the greenhouse leaf test to confirm resistant $\mathrm{CBB}$ reaction. The lines were tested with two $X c p$ isolates (DR-7 and SC4A) in a greenhouse using an RCBD with four replications, including the parents and the susceptible check 'Othello'.

\section{Results}

\section{Marker-assisted selection}

The molecular marker assays for the RAPD E4.1150, AP7, $\mathrm{Y} 7, \mathrm{P} 8$ and SCAR BC420, markers in the $\mathrm{BC}_{1} \mathrm{~F}_{1}$ and $\mathrm{BC}_{2} \mathrm{~F}_{1}$ populations (Table 1) confirmed the effect the XAN 159derived QTL have on CBB resistance. Averaged across populations, the B6 QTL linked with the BC420 SCAR marker explained $22 \%$ of the phenotypic variation $\left(R^{2}\right)$ for CBB reaction and the $\mathrm{B} 8$ QTL linked with the E4.1150 RAPD marker explained $20 \%$ (Table 1). The QTL on B10 linked with the AP7 RAPD marker (not to be confused with the SAP6 SCAR marker) had only a minor effect, explaining $9.5 \%$ of the variation in CBB reaction (Table 1). With all three markers
BC420 SCAR, E4.1150 and AP7 present, mean percentage $\mathrm{CBB}$ infection on inoculated leaves was 14 and $1 \%$ for $\mathrm{BC}_{1} \mathrm{~F}_{1}$ and $\mathrm{BC}_{2} \mathrm{~F}_{1}$ populations, respectively.

Advanced backcross lines NE-01-8, NE-01-15 and NE-01-17 (Table 3) are being considered for release as germplasm lines for improving $\mathrm{CBB}$ resistance within the pinto market class. These three lines possess the QTL on B8 (SU91) derived from XAN 159 as well as the QTL on B10 (SAP6) from 'Chase'. These two QTL were identified in most of the CBB-resistant advanced $\mathrm{BC}$ lines with acceptable pinto seed coat colour (Table 2).

\section{Field evaluation}

Field performance of advanced backcross lines revealed levels of $\mathrm{CBB}$ resistance, yield, seed weight and seed coat colour comparable with the recurrent parent 'Chase' (Table 3). Five $\mathrm{BC}_{4} \mathrm{~F}_{5}$ and four $\mathrm{BC}_{5} \mathrm{~F}_{4}$ lines showed similar $\mathrm{CBB}$ resistance to the donor parent $\mathrm{XAN} 159$. Three $\mathrm{BC}_{4} \mathrm{~F}_{5}$ lines had significantly higher seed weight than 'Chase' (Table 2).

Ten advanced backcross lines yielded more than 'Chase' (Table 3). The darker seed coat colour of 'Chase' has a limited market potential and thus production because consumers prefer pinto beans with a lighter background colour. Five $\mathrm{BC}_{5}$ and six $\mathrm{BC}_{4}$ lines had better $b$-values for reduced yellowing, and eight $\mathrm{BC}_{5}$ and $11 \mathrm{BC}_{4}$ lines had better $L$-values for brighter seed colour than 'Chase'.

Two $\mathrm{BC}_{5}$ (no. 3 and 8 ) and seven $\mathrm{BC}_{4}$ lines (no. 15, 16, 17, $25,26,28$, and 29) with acceptable seed colour, superior yield and level of CBB resistance across multiple trials (Table 3) are currently undergoing advanced yield trials for release as a new pinto bean cultivar with improved $\mathrm{CBB}$ resistance. For instance, in addition to its high $\mathrm{CBB}$ resistance comparable with XAN 159, the line NE-01-8 consistently yielded 17 and $29 \%$ higher than recurrent parent 'Chase' in Nebraska and Washington, respectively (Table 3 ).

\section{Discussion}

The results of the current study showed that molecular markers developed in a test population $(\mathrm{XAN} 159 \times$ PC50) for $\mathrm{CBB}$ resistance can be used in another population in a backcross breeding programme. First, Park et al. (1999) showed that the molecular markers developed in the test population were associated with the CBB resistance derived from XAN 159. Park et al. (1999) observed that the BC420
Table 2: Assay of advanced pinto $\mathrm{BC}$ lines with $\mathrm{CBB}$ resistance for markers linked with QTL conditioning resistance to $\mathrm{CBB}$

\begin{tabular}{|c|c|c|c|c|c|}
\hline \multirow[b]{2}{*}{ Line } & \multirow[b]{2}{*}{ Generation } & \multirow[b]{2}{*}{ Seed colour (allele) } & \multicolumn{3}{|c|}{ Markers linked to $\mathrm{CBB} / \mathrm{LG}^{1}$} \\
\hline & & & SAP6 (B10) & SU91 (B8) & BC420 (B6) \\
\hline $54-2$ & $\mathrm{BC}_{5} \mathrm{~F}_{3}$ & Black pinto $(V)$ & $+^{2}$ & - & + \\
\hline $54-3$ & $\mathrm{BC}_{5} \mathrm{~F}_{3}$ & Black pinto $(V)$ & + & - & + \\
\hline $54-4$ & $\mathrm{BC}_{5} \mathrm{~F}_{3}$ & Black pinto $(V)$ & + & + & + \\
\hline $56-1$ & $\mathrm{BC}_{5} \mathrm{~F}_{3}$ & Normal pinto $(v)$ & + & - & - \\
\hline $61-2 \mathrm{~A}$ & $\mathrm{BC}_{5} \mathrm{~F}_{3}$ & Normal pinto $(v)$ & + & + & - \\
\hline $61-2 B$ & $\mathrm{BC}_{5} \mathrm{~F}_{3}$ & Normal pinto $(v)$ & + & + & - \\
\hline $61-5 \mathrm{~A}$ & $\mathrm{BC}_{5} \mathrm{~F}_{3}$ & Normal pinto $(v)$ & + & + & - \\
\hline $61-5 B$ & $\mathrm{BC}_{5} \mathrm{~F}_{3}$ & Normal pinto $(v)$ & + & + & - \\
\hline $3-27$ & $\mathrm{BC}_{4} \mathrm{~F}_{6}$ & Normal pinto $(v)$ & + & + & - \\
\hline N1-2 & $\mathrm{BC}_{5} \mathrm{~F}_{5}$ & Normal pinto $(v)$ & + & + & - \\
\hline
\end{tabular}

${ }^{1}$ Linkage groups (LG) as reported by Freyre et al. (1998).

${ }^{2}+$ and - indicate presence and absence of the marker, respectively. 
Table 3: Advanced pinto BC lines ('Chase' $\times$ 4/XAN 159) evaluated for CBB reaction in the greenhouse and field, and for seed yield, weight and colour

\begin{tabular}{|c|c|c|c|c|c|c|c|c|c|}
\hline \multirow[b]{3}{*}{ Lines/cultivars } & \multicolumn{3}{|c|}{$\mathrm{CBB}$ reaction } & \multicolumn{2}{|c|}{ Yield $^{1}$} & \multicolumn{2}{|c|}{ Seed weight } & \multicolumn{2}{|c|}{ Seed colour ${ }^{2}$} \\
\hline & \multicolumn{2}{|c|}{ Field } & \multirow{2}{*}{$\begin{array}{c}\text { GH } \\
{[2002(\%)]}\end{array}$} & \multirow{2}{*}{$\begin{array}{c}2001 \\
(\mathrm{~kg} / \mathrm{ha})\end{array}$} & \multirow{2}{*}{$\begin{array}{c}2002 \\
(\mathrm{~kg} / \mathrm{ha})\end{array}$} & \multirow{2}{*}{$\begin{array}{c}2001 \\
\text { (g/100 seeds) }\end{array}$} & \multirow{2}{*}{$\begin{array}{c}2002 \\
\text { (g/100 seeds) }\end{array}$} & \multirow{2}{*}{$\begin{array}{l}2001 \\
\left(L^{*}\right)\end{array}$} & \multirow{2}{*}{$\begin{array}{r}2001 \\
\left(b^{*}\right)\end{array}$} \\
\hline & $2001(\%)$ & $2002\left(1\right.$ to $\left.5^{3}\right)$ & & & & & & & \\
\hline ‘Othello’ (S) & 59 & 4.3 & 100 & 2603 & 4235 & 33 & 43 & 40.2 & 9.5 \\
\hline ‘Chase' (MR) & 33 & 2.5 & 46 & 2647 & 3600 & 32 & 42 & 41.8 & 10.8 \\
\hline XAN 159 (R) & 8 & 1.0 & 5 & 2007 & 1299 & 20 & 24 & 33.5 & - \\
\hline \multicolumn{10}{|l|}{$B C_{5 \cdot 6}$ lines } \\
\hline NE7-01-2 (R) & 6 & 1.0 & - & 2642 & 3460 & 28 & 38 & 42.1 & 10.5 \\
\hline NE7-01-3 (R) & 17 & 2.0 & 4 & 2817 & 3565 & 31 & 37 & 40.6 & 9.9 \\
\hline NE7-01-5 (S) & 33 & 3.5 & - & - & 5470 & - & 41 & - & - \\
\hline NE7-01-6 (R) & 6 & 1.3 & - & 2692 & 4342 & 27 & 35 & 42.0 & 10.4 \\
\hline NE-01-7 (S) & 41 & 3.8 & - & - & 4811 & - & 39 & - & - \\
\hline NE7-01-8 (R) & 6 & 1.0 & 6 & 3103 & 4640 & 29 & 35 & 41.4 & 10.0 \\
\hline NE7-01-10(R) & 7 & 1.0 & - & 2875 & 4843 & 27 & 39 & 44.4 & 11.1 \\
\hline NE7-01-12(R) & 7 & 1.0 & - & 2026 & 4823 & 26 & 35 & 45.6 & 10.8 \\
\hline \multicolumn{10}{|l|}{$B C_{4: 5}$ lines } \\
\hline NE7-01-15(R) & 12 & 1.8 & 11 & 2516 & 3688 & 33 & 44 & 43.1 & 10.6 \\
\hline NE7-01-16(R) & 14 & 1.5 & 2 & 2958 & 3380 & 32 & 40 & 43.5 & 10.3 \\
\hline NE7-01-17(R) & 12 & 1.5 & 9 & 2628 & 4071 & 31 & 43 & 44.2 & 10.6 \\
\hline NE7-01-22(R) & 6 & 1.0 & - & 2153 & 3804 & 31 & 43 & 43.7 & 10.8 \\
\hline NE7-01-25(R) & 8 & 1.0 & 9 & 2080 & 3501 & 35 & 44 & 41.7 & 10.4 \\
\hline NE7-01-26(R) & 10 & 1.0 & 1 & 2143 & 3101 & 34 & 45 & 43.5 & 10.8 \\
\hline NE7-01-27(R) & 5 & 1.3 & - & 1857 & 3045 & 35 & 43 & 42.9 & 10.7 \\
\hline NE7-01-28(R) & 14 & 1.3 & 0 & 2104 & 3266 & 35 & 45 & 40.7 & 9.8 \\
\hline NE7-01-29(R) & 10 & 1.3 & 0 & 2148 & 3591 & 34 & 41 & 40.6 & 9.9 \\
\hline $\operatorname{LSD}(0.05)$ & 9.2 & 1.0 & 5.4 & 182 & 998 & 2.5 & 3.5 & 4.2 & 1.2 \\
\hline
\end{tabular}

${ }^{1}$ The 2001 and 2002 yield and seed weight data are from field tests conducted in Mitchell, NE and Prosser, WA respectively.

${ }^{2} L^{*}$-value $=$ seed coat colour for seed brightness factor, higher $L^{*}$-values indicate brighter seed coat colour; $b^{*}$-value $=$ seed coat colour for yellowness factor, lower $b^{*}$-values indicate less yellowing.

${ }_{3}^{3}$ Per cent CBB infection in field rated 1 to 5 , where 1 is no symptoms and 5 is $50-100 \%$ infection.

SCAR (B6), and RAPD markers E4.1150 (B8) and AP7 (B10) explained 21,14 and $17 \%$ of the phenotypic variation for $\mathrm{CBB}$ reaction in an $\mathrm{F}_{2}$ population derived from the cross, 'Chase' and XAN 159. Secondly, the same markers explained a similar variation for reaction in $\mathrm{BC}_{1} \mathrm{~F}_{1}$ and $\mathrm{BC}_{2} \mathrm{~F}_{1}$ populations of this study. The three markers for $\mathrm{CBB}$ resistance found by Jung et al. (1997) in XAN $159 \times$ PC50 were found to remain associated with that trait in the backcross generations of the cross 'Chase' and XAN 159. Thus, this is an important step in utilizing these molecular markers in MAS. The results of this study proved that these markers can be used in MAS in the future to transfer the QTL for CBB resistance within and between bean market classes. Single multiplex PCR described by Miklas et al. (2000) for SCAR markers BC420, SAP6 and SU91 should facilitate marker screening in a breeding programme. Similar results were reported in studies where QTL for resistance to pests in various crops were transferred through MAS (Toojinda et al. 1998, Robert et al. 2001, Willcox et al. 2002, Zhou et al. 2003).

The QTL on B6, B8 and B10 linked with the respective $\mathrm{BC} 420, \mathrm{E} 4.1150$ and AP7 markers are derived from the donor parent XAN 159 which also possesses the $V$ gene that conditions purple flower colour and dark seed colour. The higher $R^{2}$ values (single-factor ANOvA test) for $V$ indicate that it must be closer to the QTL governing CBB resistance on linkage group B6 than the linked DNA markers BC420, Y7 or P8 (Table 1). The tight linkage of the B6 QTL with $V$ will negate its deployment in pinto bean, which requires a recessive $v$ for the expression of a light brown mottle on a cream background, typical of the pinto bean market class. In fact, the only market classes amenable to introgression of the B6 QTL from XAN 159 will be those with white, black, or blackmottled seed coat colours. The black and black-mottled beans normally require $V$ for expression of the black colour. Beans with white seed colour possess the recessive $p$ gene, which is epistatic to all other seed coat colour genes. Thus, white-seeded navy beans can possess $V$ because it will not be expressed. The navy bean lines HR65 and HR67 possess the B6 QTL for CBB resistance from XAN 159 as determined by the presence of the linked BC420 SCAR marker (Yu et al. 2000). Similarly, Fourie and Herselman (2002) used markers to detect the effective transfer of the B6 and B8 QTL from XAN 159 into 'Teebus' navy bean by traditional backcross breeding.

The frequency distributions for disease reaction among $\mathrm{BC}_{n} \mathrm{~F}_{1}$ plants (Fig. 1) were skewed towards resistant plants in the earlier $\mathrm{BC}_{3}$ generation and towards susceptible plants in the later $\mathrm{BC}_{5}$ generation. Uniform disease reaction of the parents and susceptible check PC50 across the three generations indicated disease pressure was equal; therefore, the shift from resistance to susceptibility is likely because of genetic reasons. For the $\mathrm{BC}_{3}$ to $\mathrm{BC}_{5}$ generations, selection of resistant $F_{1}$ plants for the next backcross cycle was based on disease reaction phenotype. However, plants were also selected for acceptable pinto seed type and size. In the absence of MAS, it is plausible that minor genes that contribute to resistance, such as the B10 QTL linked with the AP7 marker, would be lost during succeeding backcrosses.

The frequency distribution for disease reaction among $\mathrm{BC}_{4} \mathrm{~F}_{2}$ plants was bimodal, and in the $\mathrm{BC}_{5} \mathrm{~F}_{2}$ population it 
(a)
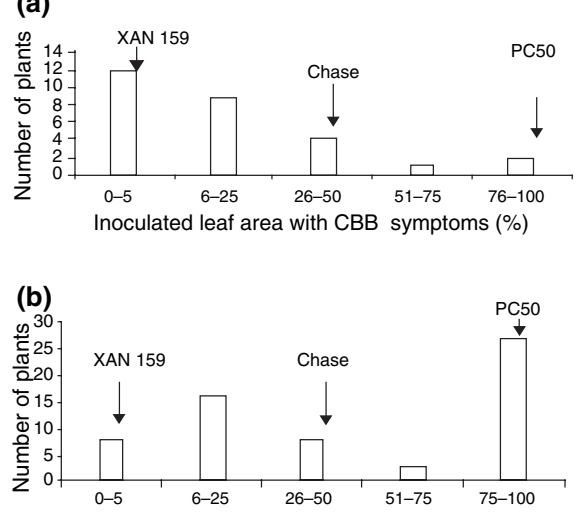

Inoculated leaf area with CBB symptoms (\%)

(c)

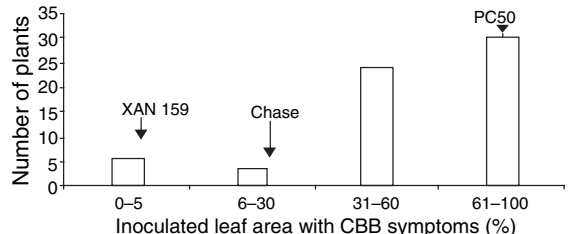

(d)
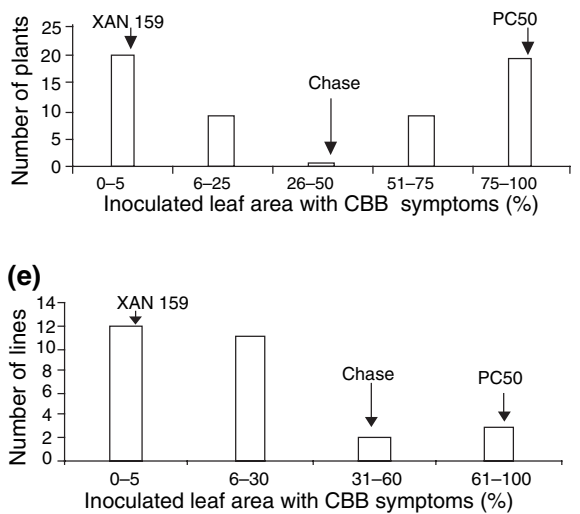

Fig 1: Frequency distributions of 'Chase' $\times$ XAN 159 backcross populations; A, B, C, D, and $\mathrm{E}$ showing \% of inoculated leaf area with $\mathrm{CBB}$ symptoms for $\mathrm{BC}_{3} \mathrm{~F}_{1}$, $\mathrm{BC}_{4} \mathrm{~F}_{1}, \mathrm{BC}_{5} \mathrm{~F}_{1}, \mathrm{BC}_{4} \mathrm{~F}_{2}$, and $\mathrm{BC}_{5} \mathrm{~F}_{2}$ respectively

was skewed towards resistance (Fig. 1). The resistance possessed by the recurrent parent 'Chase' would become fixed in the later generation backcrosses. This stabilization of resistance from the recurrent parent in later backcross generations combined with the introgressed but still segregating resistance from the donor parent XAN 159 would contribute to segregation skewed towards resistance as observed for the $\mathrm{BC}_{5} \mathrm{~F}_{2}$ population.

From the $\mathrm{BC}_{3} \mathrm{~F}_{3}$ to $\mathrm{BC}_{5} \mathrm{~F}_{3}$ generations, the non-commercial black-mottled pinto bean lines that possessed $V$ were selected against. An assay of the SCAR markers linked with the B6 (BC420) and B8 (SU91) QTL revealed that the linkage association between BC420 SCAR marker and $V$ had not been broken (Table 2). All $\mathrm{BC}_{5} \mathrm{~F}_{3}$ plants with $\mathrm{BC} 420$ marker had black mottled pinto seed coat colour patterns, and those without BC420 had normal pinto seed type. Thus, although advanced pinto lines with improved levels of resistance to $\mathrm{CBB}$ were obtained (Table 3), none possessed the B6 QTL for resistance.

Three $\mathrm{BC}_{4} \mathrm{~F}_{5}$ lines had significantly higher seed weight than 'Chase', indicating the linkage between QTL for resistance to CBB and small seed size in XAN 159 as reported by Park et al. (2000) was either broken or the genomic region(s) possessing the linkage was not introgressed. The latter explanation is most likely. The B6 QTL had the highest correlation with small seed size in the PC50/XAN 159 population (Park et al. 2000), but was not introgressed into 'Chase' because of its tight linkage with $V$ (Table 2).

In summary, backcross breeding with the aid of molecular markers was used to obtain advanced pinto bean lines with high levels of CBB resistance. Agronomic characteristics of the recurrent parent, 'Chase' pinto, were fully recovered. In fact, slightly higher yield and brighter seed colour than 'Chase' pinto were observed in a few advanced backcross lines. The high level of resistance was achieved, in part, by a combination of two QTL. One QTL from GN no. 1 Sel 27 was already present in 'Chase' on linkage group B10 as evidenced by presence of SAP6 marker and the other QTL on linkage group B8 was introgressed from XAN 159 as evidenced by the presence of the SU91 marker. The enhanced level of resistance obtained was expressed across both field and greenhouse environments. The MAS for two major and one minor QTL for $\mathrm{CBB}$ resistance combined with phenotypic selection was highly effective in early $\mathrm{BC}$ generations. The use of molecular markers in backcross breeding will be an effective strategy for improving genetic resistance for $\mathrm{CBB}$ in the bean market classes.

\section{References}

Aggour, A. R., D. P. Coyne, and A. K. Vidaver, 1989: Comparison of leaf and pod disease reactions of beans (Phaseolus vulgaris L.) inoculated by different methods with strains of Xanthomonas campestris pv. phaseoli (Smith) Dye. Euphytica 43, 143-152.

Coyne, D. P. and M. L. Schuster, 1974: Differential reaction of pods and foliage of beans (Phaseolus vulgaris) to Xanthomonas phaseoli. Plant Dis. Rep. 58, 278-282.

Coyne, D. P., D. S. Nuland, D. T. Lindgren, and J. R. Steadman, 1994: 'Chase' pinto dry bean. HortScience 29, $44-45$.

Fourie, D., and L. Herselman, 2002: Breeding for common blight resistance in dry beans in South Africa. Annu. Rep. Bean Improv. Coop. 45, 50-51.

Freyre, R., P. Skroch, Y. Geffroy, A. F. Adam-Blonden, A. Shirmohammadali, W. Johnson, V. Llaca, R. Nodari, P. Pereira, S. M. Tsai, J. Tohme, M. Dron, J. Nienhuis, and P. Gepts, 1998: Towards an integrated linkage map of common bean. 4. Development of a core map and and alignment of RFLP maps. Theor. Appl. Genet. 97, 847-856.

Jung, G., P. W. Skroch, D. P. Coyne, J. Nienhuis, E. Arnaud Santana, H. M. Ariyarathen, S. M. Kaeppler, M. J. Bassett, and G. H. Jung, 1997: Molecular-marker-based genetic analysis of tepary beanderived common bacterial blight resistance in different developmental stages of common bean. J. Am. Soc. Hort. Sci. 122, 329-337.

Kelly, J. D., P. Gepts, P. N. Miklas, and D. P. Coyne, 2003: Tagging and mapping of genes and QTL and molecular marker-assisted selection for traits of economic importance in bean and cowpea. Field Crops Res. 82, 135-154. 
McElroy, J. B., 1985: Breeding dry beans, Phaseolus vulgaris L., for common bacterial blight resistance derived from Phaseolus acutifolius A. Gray. Diss. Abstracts Int., B Sciences and Engineering 46, 2192B.

Miklas, P. N., E. Johnson, V. Stone, J. S. Beaver, C. Montoya, and M. Zapata, 1996: Selective mapping of QTL conditioning disease resistance in common bean. Crop Sci. 36, 1344-1351.

Miklas, P. N., J. R. Smith, R. Riley, K. F. Grafton, S. P. Singh, G. Jung, and D. P. Coyne, 2000: Marker-assisted breeding for pyramided resistance to common bacterial blight in common bean. Annu. Rep. Bean Improv. Coop. 43, 39- 40.

Miklas, P. N., D. P. Coyne, K. F. Grafton, N. Mutlu, J. Reiser, D. Lindgren, and S. P. Singh, 2003: A major QTL for common bacterial blight resistance derives from the common bean great northern landrace cultivar Montana No. 5. Euphytica 131, 137-146.

Park, S. O., D. P. Coyne, N. Mutlu, G. Jung, and J. R. Steadman, 1999: Confirmation of molecular markers and flower color associated with QTL for resistance to common bacterial blight in common beans. J. Am. Soc. Hort. Sci. 124, 519-526.

Park, S. O., D. P. Coyne, G. Jung, P. W. Skroch, E. Arnaud Santana J. R. Steadman, H. M. Ariyarathne, and J. Nienhuis, 2000: Mapping of QTL for seed size and shape traits in common bean. J. Am. Soc. Hort. Sci. 125, 446- 475.

Paterson, A. H., S. Damon, J. D. Hewitt, D. Zamir, H. D. Rabinowitch, S. E. Lincoln, E. S. Lander, and S. D. Tanksley, 1991: Mendelian factors underlying quantitative traits in tomato: comparison across species, generations, and environments. Genetics 127, 181-197.

Pedraza, F., G. Gallego, S. Beebe, and J. Tohme, 1997: Marcadores SCAR y RAPD para la resistencia a la bacteriosis comun (CBB). In: S. P. Singh, and O. Voysest (eds), Taller de mejoramiento de frijol para el Siglo XXI: Bases para una estrategia para America Latina, 130-134. CIAT, Cali, Colombia.

Robert, V. J. M., M. A. L. West, S. Inai, A. Caines, L. Arntzen, J. K. Smith, and D. A. St-Clair, 2001: Marker-assisted introgression of blackmold resistance QTL alleles from wild Lycopersicon cheesmanii to cultivated tomato ( $L$. esculentum) and evaluation of QTL phenotypic effects. Mol. Breeding 8, 217-233.

SAS, 1981: SAS/STAT guide for personal computers, 6th ed. SAS Institute, Carry, NC, USA.
Schuster, M. L., D. P. Coyne, T. Behre, and G. Leyna, 1983: Sources of Phaseolus species resistance and leaf and pod differential reactions to common blight. HortScience 18, 901-903.

Singh, S.P, 2001: Broadening the genetic base of common bean cultivars: a review. Crop Sci. 41, 1659-1675.

Singh, S. P. and C. G. Munoz, 1999: Resistance to common bacterial blight among Phaseolus species and common bean improvement. Crop Sci. 39, $80-89$.

Singh, S. P., C. G. Munoz, and H. Teran, 2001: Registration of common bacterial blight resistant dry bean germplasm VAX 1, VAX 3, and VAX 4. Crop Sci. 41, 275-276.

Skroch, P. W., and J. Nienhuis, 1995: Qualitative and quantitative characterization of RAPD variation among snap bean (Phaseolus vulgaris) genotypes. Theor. Appl. Genet. 91, 1078-1085.

Tar'an, B., T. E. Michaels, and K. P. Pauls, 1998: Stability of the association of molecular markers with common bacterial blight resistance in common bean (Phaseolus vulgaris L.). Plant Breeding 117, $553-558$.

Thomas, C. V., and J. G. Waines, 1984: Fertile backcross and allotetraploid plants from crosses between tepary beans and common beans. J. Hered. 75, 93-98.

Toojinda, T., E. Baird, A. Booth, L. Broers, P. Hayes, W. Powel, W. Thomas, H. Vivar, and G. Young, 1998: Introgression of quantitative trait loci (QTL) determining stripe rust resistance in barley: an example of marker-assisted line development. Theor. Appl. Genet. 96, $123-131$.

Willcox, M. C., M. M. Khairallah, D. Bergvinson, J. Crossa, J. A. Deutsch, G. O. Edmeades, D. Gonzales-de-Leon, C. Jiang, D. C. Jewell, J. A. Mihm, and W. P. Williams, 2002: Selection for resistance to southwestern corn borer using marker-assisted selection and conventional backcrossing. Crop Sci. 42, 1516-1528.

Yu, K., S. J. Park, and V. Poysa, 2000: Marker-assisted selection of common beans for resistance to common bacterial blight: efficacy and economics. Plant Breeding 119, 411-415.

Zhou, W. C., F. L. Kolb, G. H. Bai, L. L. Domier, L. K. Boze, and N. J. Smith, 2003: Validation of a major QTL for scab resistance with SSR markers and use of marker-assisted selection in wheat. Plant Breeding 122, 40-46. 